\title{
THE SUSTAINABLE UNIVERSITY - A MODEL FOR THE SUSTAINABLE ORGANIZATION
}

\author{
Valentin, GRECU ${ }^{1}$ and Nagore, IPIÑA ${ }^{2}$ \\ Lucian Blaga University of Sibiu, Sibiu, Romania, valentin.grecu@ulbsibiu.ro \\ Mondragon University, Mondragon, Spain, nipina@mondragon.edu
}

\begin{abstract}
The issue of sustainable development (SD) is increasingly present among the concerns of the international academic community. However, the depth of our unsustainable practices suggests that insufficient progress has been made to move from an unsustainable lifestyle to sustainable development. By sharing ideas, concepts, tools, experiences learned in different contexts, it is anticipated that we will all learn many things that will help us to help our academic communities and companies to develop the skills to make progress towards sustainable development.

In response to increasing concerns of society about environmental degradation and increasing demands for a transition to a more sustainable society, the business companies are increasingly active in aligning their processes and services with a sustainability agenda. A good management of environmental services has now become the focus of many business strategies tending to the aspiration of 'greening' their infrastructures and product deliveries. The growing demand for "green" products has created major new markets in which visionary entrepreneurs reap the rewards of approaching sustainability. Hence, by adopting sustainable practices, companies can gain competitive advantage, increase market share and boost shareholder value.

The sustainable university can be am model for the organizations that want to embark in the process of transition towards sustainability. This paper presents a model of the sustainable university and the steps that the management of such an organization should follow in order to transform their institution into a green one.
\end{abstract}

KEY WORDS: Sustainable University, Sustainable Management, Green Organizations, Transition Towards the Sustainable Society.

\section{INTRODUCTION}

The role of education in shaping the future is widely recognized. The world is becoming more complex, interdependent and unsustainable and this calls for a change in lifestyle. Thus, education for sustainable development is given increased attention in universities worldwide. Transformation of education into sustainability education implies systemic thinking and interdisciplinary approaches. However, as in all relevant and visionary new actions, where people are committed, there is always a period of "boiling" which is necessary to develop and transmit ideas, to launch extensive discussions, to refine the concepts, to correct and adjust them.

This occurs in sustainable development in higher education. Many new educational approaches are tested. Some work in certain locations, but not yet tested in other locations, we do not know if they have more application or if they must be adapted to each new cultural or geographical context.

By sharing ideas, concepts, tools, experiences learned in different contexts, it is anticipated that we will all learn many things that will help us to help our academic communities and companies to develop the skills to make progress towards sustainable development.

A number of scholars, including John Blewitt [1], John Fien [2], Walter Filho [3], Joy Palmer [4], Stephen Sterling [5] and
Daniella Tilbury [6] continue to make many important contributions, both informing and challenging academic and practitioner thinking about education-for-sustainability in higher education.

Universities, in particular, are designed to develop their students' so-called dynamic qualities [7] that allow them to analyze, build and operate with a high degree of autonomy and selfdetermination, if not in their personal lives, then at least in their professional life. At the same time, universities should develop to students skills which will allow them to cope in situations of uncertainty, and vaguely defined norms, values, interests and construction of reality that are conflicting or at least divergent [8].

Education should contribute to creating a (more?) just world from the democratic and ecological point of view - however it would look. Education is seen as a way to become fulfilled members of society that seek meanings, develop their potential and find solutions together. A sustainable world can not be created without the full involvement of all members and democratic society, a sustainable world without participation and democracy is unimaginable [9].

\section{SUSTAINABLE UNIVERSITY}

An important attempt to define what "sustainable university" means was made in 1990, by the Declaration of Talloires. Jean Mayer, president of Tufts University, U.S.A., convened 22 
university leaders in Talloires, France, to express their concerns about the state of the world and elaborate a document which to identify the key actions that universities must make to create a sustainable future. Identifying the deficit of specialists in environmental management and its related fields, and lack of understanding of professionals in all areas, of the consequences of their actions on the environment and public health, this meeting pre-defined the role of the university:

"Universities educate individuals most responsible for developing and organizing social institutions. For this reason universities have huge responsibility to raise awareness, knowledge, technology and development tools needed to create an environmentally sustainable future" [10].

The Talloires Declaration (TD) is a ten-point action plan for incorporating sustainability and environmental literacy in teaching, research, operations and outreach at colleges and universities. It has been signed by over 350 university presidents and chancellors in over 40 countries. The signers of the Talloires Declaration committed themselves to take the following actions [10]:

1. "Increase Awareness of Environmentally Sustainable Development

2. Create an Institutional Culture of Sustainability

3. Educate for Environmentally Responsible Citizenship

4. Foster Environmental Literacy For All

5. Practice Institutional Ecology

6. Involve All Stakeholders

7. Collaborate for Interdisciplinary Approaches

8. Enhance Capacity of Primary and Secondary Schools

9. Broaden Service and Outreach Nationally and Internationally

\section{Maintain the Movement.'}

The sustainable university has been defined by Velazquez et al. [11:812] as:

"a higher educational institution, as a whole or as a part, that addresses, involves and promotes, on a regional or a global level, the minimization of negative environmental, economic, societal, and health effects generated in the use of their resources in order to fulfil its functions of teaching, research, outreach and partnership, and stewardship in ways to help society make the transition to sustainable life-styles."

The model of a sustainable university, proposed in this paper will be analyzed and an improved version of this model is proposed.

\subsection{Transition towards a Sustainable University}

In response to increasing concerns of society about environmental degradation and increasing demands for a transition to a more sustainable society, higher education institutions worldwide have begun to change their missions and educational practices and approaches to include sustainability. Because this happened in the past decade, the role of higher education in the social context of an ongoing transition to greater sustainability has become a topic of significant scientific importance $[3,12]$.

Although this emerging literature on sustainability in higher education is diverse, it is dominated by empirical and descriptive, specific approaches, strategies and initiatives in specific institutions [13], but also includes prescriptive studies that often call to universities to play a more prominent role in education for sustainability $[3,14,15]$. Much of the descriptive literature, so far, is focused on specific strategies or actions taken at specific institutions [16].

\subsection{Benefits of transforming into a sustainable university}

Universities have different organizational cultures that value and promote learning and thus can play a vital role in the transformation of society based on educating new generations of citizens and leaders. Higher education has always been responsive to social needs, and history of higher education demonstrates an evolution of the structure and goals of universities that directly reflect the dynamics of systems of the socio-technical society [17].

Cortese [18:1] argues that some changes in human activities which will flow from transforming the university into a sustainable one by shifting the paradigm towards a systemic perspective which encompasses the complex interdependence of individual, social, cultural, economic and political activities and the biosphere, include the following:

- "Future scientists, engineers and business people will design technology and economic activities that sustain rather than degrade the natural environment, enhance human health and wellbeing, and mimic and live within the limits of natural systems.

- All professionals will understand their connection to the natural world and to other humans. They will know where products and services come from, where wastes go and what they do to humans and other living species. They will understand how to minimize this "ecological footprint."

- All current and future generations of humans will be able to meet their basic needs, pursue meaningful work and have the opportunity to realize their full human potential personally and socially."

\section{SUSTAINABILITY IN THE BUSINESS SECTOR}

The business sector is responsible for a significant proportion of the environmental footprint, in addition to having a major influence on wider social and economic sustainability issues, both nationally and internationally [19]. Therefore, it is crucial to improve the environmental and sustainability performance of businesses and organizations in order to achieve a more sustainable society

A sustainable business is any organization participating in ecological or green activities to ensure that all processes, products and production activities adequately address the current environmental concerns, while maintaining a profit [20]. In other words, it is a business that "meets the needs of the present world without compromising the ability of future generations to meet their own needs" [21]. Generally, a business is considered to be green if it meets the following four criteria [22]:

1. Incorporates sustainability in each of its business decisions;

2. Provides environmental products and services that replace the demand for products and / or organic services;

3. It is greener than traditional competition; 
4. Made a commitment to the principles of environmental sustainability in its business operations.

The turn of the 'green' in business has been associated with a multitude of conceptions and practical ideas. Authors like Keijzers [23], Rennie [20], Galvao [24], and Matthews [25], attempted to define sustainable business or green business as business that not only curb pollution, ensure re-use of renewables and recyclable resources, and preserve natural resource stocks, but also respond to customer needs while at the same time leaving no negative impact on the environment, community, society and economy.

However, customers, financial partners, non-governmental organizations, governments, the globalization of economies and internationalization of social and environmental standards exert new pressures on companies to take on social and ecological responsibilities. Over the last decade, there has been an increased pressure on enterprises to broaden the focus of sustainability and accountability in business performance beyond that of financial performance. Demands for sustainability management spring from a variety of sources, including societal mandates incorporated into regulations, fear of loss of sales, and a potential decline in reputation if a firm does not have a tangible commitment to corporate sustainability management [26]. As a response, companies start to contribute to the development of sustainable energy and transport infrastructures, and in designing and implementing new sustainable technologies [23].

Although industry is sometimes seen as a source of environmental degradation and social concerns, it is widely recognized that it is an essential part of development and wealth creation. Therefore, as an important social actor, industry must play a prominent role in creating a sustainable future [27]. The challenge of sustainable development for any business is to ensure that it contributes to a better quality of life today without compromising the quality of life of future generations. If industry is to respond to this challenge, it needs to demonstrate a continuous improvement of its triple bottom line, i.e. economic, social, and environmental performance, within new and evolving governance systems [28].

Furthermore, environmental (e.g. climate change) and social (e.g. accountability) demands from shareholders and stakeholders are contributing to the pressure for companies to consider sustainability issues more seriously. However, the major challenge to companies and industries is to demonstrate their current contribution to the society as a whole without compromising the potential for continuing to deliver improvements or future generations. In short, sustainability management practices at a firm level may help the management board to align its corporate and business strategy and to meet key sustainability challenges [29].

\section{MODELS OF SUSTAINABLE UNIVERSITIES}

Some of the literature on education for sustainable development seeks to identify best practices in one institution or set of institutions [30]. This approach can develop an ambitious vision of how an ideal sustainable university would look once it reaches the stage of "stabilization", but there is the risk of minimizing significant dynamics in the real world. For example, assuming that an ideal, stabilized state can actually be achieved, can be quite daunting for potential change agents, whose universities are far from the 'ideal' in a number of areas. What best practices analysis omits is precisely how these practices have been developed - and how these practices can have an impact in different contexts and cultures and can actually be considered "best" practices.

A very complex model of the Sustainable University was developed by Velazquez et al. [11]. Their model aims to offer a clear perspective on what people responsible for sustainability initiatives should do in order to transform their university into a sustainable one. The model was created by using a benchmarking process of the best practices used in universities for fostering sustainability in eighty higher education institutions around the world [11].

In our opinion this model can be improved with recommendations of how to transform the university into a sustainable one. The principles for integrative development process towards sustainability proposed in the Graz Model [31] were used to complete the Velazquez et al. model. The vision of the sustainable university proposed by Asitha Jayawardena [32], gave a starting point to the proposed model. Three perspectives were considered when thinking of a sustainable university: an academic approach, an internal and an external approach of the university. Other models [33, 34, 35, 36] were consulted and they also influenced the authors when creating the proposed model (figure 1).

\section{DESCRIPTION OF THE PROPOSED MODEL}

In this section, the proposed model (see fig. 1) will be explained, and its components will be discussed in detail. It is recommended to look at the diagram from its centre towards the edges. As suggested by Asitha Jayawardena [32], after considering several threads and findings, the university has to consider more perspectives into its transformation process towards a sustainable one. The academic approach is not sufficient, the community and the campus are other important aspects that should be considered.

\subsection{What universities should to in order to become sustainable?}

As illustrated in figure 1, the model proposes three different approaches of a Sustainable University. From an internal approach, the focus is on the campus and campus family; the community and the wider world are highlighted in the external approach, while the academic approach brings into light the knowledge, skills, competencies and values that the students gain during their university life.

Campus and campus family: The University, like any other organisation, consumes natural resources, produces waste and affects the environment. It employs people for providing educational service to the community, contributing in this way to economic development. As identified by Velazquez et al. [11], after consulting eighty higher education institutions and the literature, issues like: energy efficiency, equity \& poverty, water efficiency, access for disabled people, transportation \& commuting of students and staff, waste management, natural heritage, dining services, occupational health \& safety, ergonomics and environmental procurement should be addressed by the university. Further in the description of the model, we will present who should be responsible for implementing this changes.

Knowledge, skills and values: Forward-thinking universities are already acting as agents in promoting sustainability principles within society and will play an even more crucial role in the 
future [37]. The knowledge, skills and values, that a university creates, transfers and promotes, would influence and even shape the future society. The main means available for universities to equip their students with knowledge, values and skills are its core academic functions: education and research.

The whole system of education and training will have to internalize the principles and objectives of sustainable development as an integrator of the knowledge, skills and abilities necessary for existence and personal performance in the modern world. Education for sustainable development can be a distinct discipline of study but according to best practices in EU countries, it should be infused into all training programs [38], designed and organized by disciplinary fields or modules, from science to practice responsible citizenship and from sustainable production and consumption in relation to the resources, to acquiring the principles of cultural diversity, good governance and rule of law. Also, educational approach to sustainable development beyond formal, informal and non-formal components should be equally concerned.

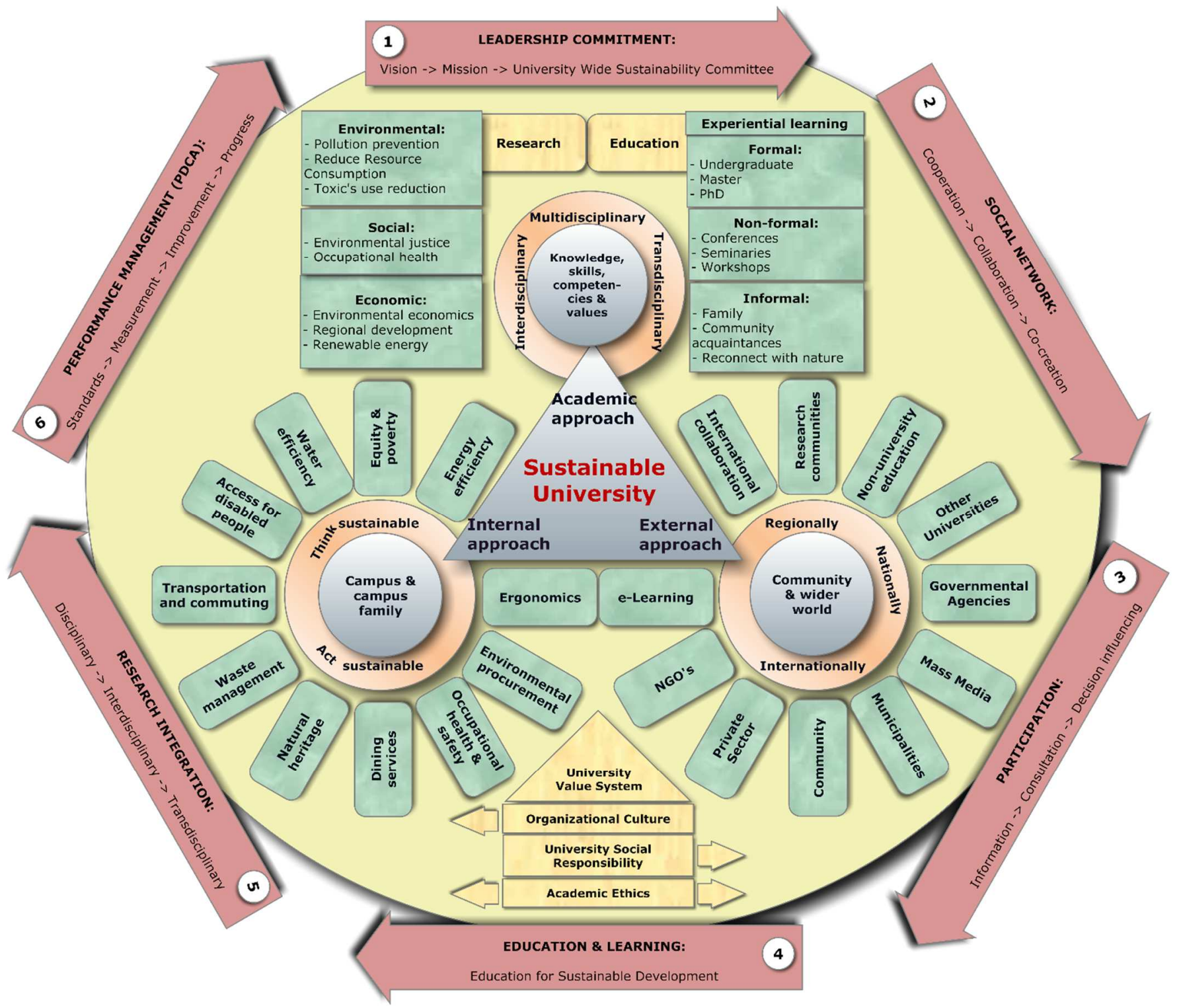

Figure 1. Model of the transformation towards the Sustainable University

The model proposes that education and research should be multi-, inter- and transdisciplinary. Rhoten et al [39] suggest 'interdisciplinary education' is:

"a mode of curriculum design and instruction in which individual faculty or teams identify, evaluate and integrate information, data, techniques, tools, perspectives, concepts and or theories from two or more disciplines or bodies of knowledge to advance students' capacity to understand issues, address problems, appraise explanations, and create new approaches and solutions that extend beyond the scope of a single discipline or area of instruction."

Klein [40] believes that interdisciplinarity is a key to universities rethinking their purposes and practices at a fundamental level. Sustainability pedagogies are diverse, complex and often different from traditional pedagogies, including participatory and inclusive education processes, transdisciplinary cooperation, experiential learning and the use of environmental and community as learning resources [41]. The proposed model doesn't focus on the pedagogies, but suggests that the 
knowledge, values and skills can be delivered to students through formal, no-formal and informal education. The model also recommends that research should focus on the three pillars of sustainability: society, economy and environment, and presents some possible research topics, for each of the three components.

Community and wider world: Universities operate, are situated, and have impacts in wider communities and ecosystems, ranging from local to global. Education for sustainable development requires cooperation and partnership between multiple stakeholders: central and local authorities, education and science sector, health sector, private sector, industry, transport and agriculture, trade unions, media, NGOs, local community, citizens and international organizations.

Developing greater synergies between universities and community (eg education in schools and adult literacy initiatives, education in schools and employment opportunities for young people, etc.) in order to address sustainable development objectives should become a priority for universities.

\subsection{How should the changes be implemented?}

It is important for universities to know what to do in order to become sustainable universities, but it is essential to know how to do it as well. The proposed model doesn't intend to be a rigid structure, as sustainability is a complex issue and it is approached differently by various actors. However, the model aims to be a guiding tool for exploring strategies for transforming the university into a sustainable one.

Velazquez et al [11:818] highlighted that "implementing the sustainable university model is a process of continual improvement in environmental, social and economic performance that should be made through incremental steps". In addition to the Velazquez et al model, we have suggested the steps to be followed, having in mind the Graz Model [31]. In addition to the 5 principles of the Graz Model (Leadership \& Vision, Social Network, Participation, Education \& Learning and Research integration), another principle was inserted to close the loop: Performance Management. These steps are illustrated in the model, pictured as the 6 arrows that form a closed loop.

\subsubsection{Leadership commitment.}

According to the strategic management process (Scheeres, 2010), the leaders of an organization develop and support the organization's core mission, vision and values, setting goals and objectives to keep the organization on course. The important role of using mission, vision and strategy has been acknowledged in most organizations today. Naaranoja et al [42:659] explained shortly that "mission is the reason why the organization exists; vision is the ideal state of the organization in the future and strategy defines the way of how to get towards the ideal state introduced in the vision." The model suggests a sequence of 3 steps, inspired from the Velazquez et al [11] model:

- Developing a Sustainability Vision for the university - this is the first step in the strategic move towards the sustainable university. "At this point, there are neither barriers nor constraints besides imagination and creativity" [11:812]. When developing the vision, attention should be given to motivating participants to take part in the process of transforming the university into a sustainable one and to use the vision later in the process as a tool for guiding the prioritizing the different needs and wishes.
- Creating a Mission - an effective mission statement describes, in simple yet powerful terms, the organization's fundamental, unique purpose. The vision should be an important basis for the development of the mission. A mission statement tends to be more realistic than a vision statement and answers three key questions: who, what and why. However, it is fundamental that when creating the university mission statement sustainability should be included as one of the core values of the university [33].

- University-Wide Sustainability Committee - the organizational structure of a university should reflect its commitment to sustainability by implementing the strategies for achieving the mission [11]. This sustainability committee should have representative members from all stakeholders groups and its attributions should be helping responsible people take decisions, disseminating and receiving information, coordinating initiatives, getting funds, developing, promoting and monitoring the implementation of policies aimed at inspiring behavioural changes of university members [11]. "When a policy is absent or is developed with broad unit input, efforts are likely to be uncoordinated, and the result will be unfocused and short-lived" [43:19].

\subsubsection{Social Network.}

Social Network is related to people who are affected by the process, as well as all relevant stakeholders. Stakeholders are represented by the human resource, whether future / current / former employees of the organization, partners, competitors, consumers, etc. For an organization to improve prospects for sustainability, it needs to create, develop and maintain an open relationship with its stakeholders. Networking between partners can streamline the activities of the organization. The model presents three stages that should be followed consequently, when creating the social network [44]:

- An Information Network simply aims to exchange information without following a common aim to combine this information.

- A Knowledge Network aims to combine information and follows a common aim. More trust towards each other in the use of one's knowledge is required.

- An Innovation Network follows a common vision, requires high trust towards each other and aims to pose new innovative solutions for coming challenges.

\subsubsection{Participation.}

Participation focuses on how all the people of the social network are involved in the process of transforming the university into a sustainable one. Leaders have found that meetings where team members openly communicate on topics of interest and participate in problem solving, yields better results than those where people sit and listen [45]. There are different levels of participation in meetings; the most desirable is a fully interactive environment.

In order to encourage people to participate in the process of transformation of the University into a sustainable one, the Graz Model [31] recommends a transition from the information level towards the participative process of governance. According to Barton and Dlouhá [44], the three steps of the transformation process - in terms of participation are:

- Information is just a one way communication without reflection. People are informed without active involvement. 
- Consultation involves relevant people by seeking interests and opinions but calls for a decision from the leader on how to react to the feedback.

- Decision influencing participation involves people in the leadership of the process and transforms a shared leadership with highly trusted people.

\subsubsection{Education \& Learning.}

According to Sterling [5:12] "it is the change of mind on which change towards sustainability depends; the difference of thinking that stands between a sustainable or a chaotic future". As Schumacher [46] observed "the volume of education ... continues to increase, yet so do pollution, exhaustion of resources, and the dangers of ecological catastrophe. If still more education is to save us, it would have to be education of a different kind: an education that takes us into the depth of things". Otherwise, as David Orr [47:5] says, "without significant precautions, [education] can equip people merely to be more effective vandals of the Earth."

Sustainability is not just another issue to be added to an overcrowded curriculum, Sterling [48:50] says, but a "gateway to a different view of the curriculum, of pedagogy, of organizational change, of policy and particularly of ethos." One can generally say that in order to learn about sustainable development, one must be acquainted with several different branches of science. Paula Lindroos [49:93] observed that

"learning about sustainable development is guided by a principle of organizing science and at the same time focusing on the problem solving capabilities of the students. This means both content and learning methods become important for the courses."

Tilbury [6:20] argues that "Environmental Education for sustainability is an innovative and interdisciplinary process requiring participative and holistic approaches to the curriculum" and considers that there is a need for innovation, rather than integration of education-for-sustainability. Hart, Jickling and Kool [50:109] also imply that environmental education should be "interdisciplinary, participatory, critical, community-based, values-based and inquiry-based."

Sterling [5, 48] advocates strongly for educational transformation to 'sustainable education' and argues for reorientation of educational policies, programmes and practices using the synergy between ecological and systemic thought. Sterling also suggests that we need to undertake an educational journey from present to future teaching pedagogies that practice sustainable education. He also contends that educational culture needs to move away from current concerns with product, to a "holistic educational paradigm concerned with the quality of relationships ... with emerging rather than predetermined outcomes" [48:43].

The model shows what many scholars have advocated for: education for sustainable development should be integrated into the practices of universities. In order to overcome the barriers which occur in the process of re-orienting teachers towards sustainable education (such as: lack of awareness that reorienting to achieve sustainability is essential; lack of clarity of what re-orienting entails; the limits of the traditional disciplinary boundaries that reward teachers for work within the confines of the discipline only; inadequate financial and general resource support for change and lack of support for innovative change [51]) the previous steps should be completed. Therefore, leadership commitment, social networking and participation should facilitate overcoming the barriers. Other instruments, such as a website for disseminating information and best practice and problems sharing, addressed mainly to the teaching community of the universities, but also to the students, could ease the transition towards sustainability education [52].

\subsubsection{Research Integration.}

Increasing the level of integration is currently an important policy objective for European research [53]). Research Integration provides the opportunity to find new solutions for existing and upcoming challenges. Integration between disciplines and between research and practice is increasingly recognized as essential to tackle complex problems more effectively. Increasingly diverse parts of universities are involved in research aimed at contributing to various aspects of sustainability. Dedicated academic departments have also been formed at many universities to undertake more integrative studies [54]. The model recommends that universities should gradually try to move from disciplinary research, (a current practice in most universities), towards interdisciplinary and transdisciplinary research. Having the previous steps of the model completed, which assumes an understanding of the sustainability issue for all the stakeholders in a university, would ease the process of research integration. The three steps of research integration, suggested by the Graz model are [44]:

- Disciplinary Research only focuses on a single discipline.

- Interdisciplinary Research creates connections between disciplines and demonstrates systemic interrelations inbetween.

- Transdisciplinary Research takes up challenges posed by the people involved and creates a mutual learning environment with interdisciplinary systemic understanding.

\subsubsection{Performance Management.}

Performance management can be defined as a mechanism to improve organisational performance by linking and aligning individual, team and organisational objectives and results. Turban et al [55] describe performance management as "a realtime system that alert managers to potential opportunities, impending problems, and threats, and then empowers them to react through models and collaboration". Critical success factors of performance management systems include their alignment with the organisation's strategic goals, their credibility within the organisation and their integration with other Human Resource Management (HRM) functions such as reward systems, learning and development and career progression and promotion [56]. De Cieri and Kramar [57] suggest that performance management has three major purposes, a strategic purpose - which includes the articulation of how the goals are to be linked, a developmental purpose - with a focus on the individual, and an administrative purpose - which includes decision making.

The use of indicators of performance as a way of managing and improving performance in education is now so widespread across schools, colleges and universities that it is difficult to imagine educational life without them [58]. The PDCA cycle proposed by W. Edwards Deming is a useful tool to coordinate continuous improvement efforts. It both emphasizes and demonstrates that improvement programs must start with careful planning, must result in effective action, and must move on again to careful planning in a continuous cycle. However, the cycle does not finish there. It is always necessary to begin the cycle again to back, to identify new and better methods.

There has been a distinctively Scottish attempt to combine selfevaluation and performance management using performance 
indicators linked to school self-evaluation, notably in 'How Good is our School?' [58]. This seeks to maintain local and school-based elements of evaluation and to combine quantitative and qualitative data to arrive at indicators of quality. These selfevaluation activities, regarding the sustainability advancement in a university, combined with classical methods of problem identification, such as interviews, Preliminary System Study, Cause Effect Diagram or Root Cause Analysis [59], and decision support systems and techniques should be used as a starting point for the PDCA cycle.

\subsection{Which are the conditions for implementing the model?}

In order to have a successful implementation of the changes towards a sustainable university, a holistic vision should be adopted. The '4C' model, proposed by Jones, Selby and Sterling [38:7], suggests that Curriculum, Campus, Community and (institutional) Culture should be seen as mutually enfolded and complementary foci of the sustainable university. In this way,

"learning programmes encompass the exploration of campus, community partnerships and initiatives, and university culture from a sustainability perspective, while student experiential and action research can be directed towards campus, community and institutional cultural change" [38:7].

Selby [60] suggests that the Policy and Action Plans should embrace a holistic notion of sustainability that, while taking the environment as fundamental, melds together economic health, social justice and other humanitarian concerns. Williams [61:22] also highlights that

"education-for-sustainability is a holistic learning process, linking learning across environmental, social, economic and cultural dimensions so that students can acquire increasing understanding of the complexity of living within resource limits."

Williams [61:216] describes the culture of a particular university as

"the product of the universal history of the establishment of universities, the development of a particular university in place and time, the nature of the student population it engages with, research and teaching funding opportunities and, amongst other influences, the need for adherence to external statutes and expectations."

She also argues that the present business culture of universities presents a barrier for the vital cross-sectoral dialogue that is needed to shift from general awareness of a need, into the realm of actually effecting the changes for student learning for sustainability [61].

In his $\mathrm{PhD}$ thesis, Sterling [5] raises some questions regarding the "nature of the change of consciousness that appears necessary to the achievement of a more ecologically sustainable society" and how we can change the way we "view and practice education and learning" in order to change the society. Given the fact that these questions concern cultural, social and personal changes, they can't be answered simply or briefly. However, Sterling [5:9] proposes an answer: whole systems thinking, which "involves an extension of perception, a quality of connection in our conceptual thinking, and integration in our planning and actions towards healthy systems."

The cultural background presented in the proposed model tries to highlight that the success of the transition towards the sustainable university depends on the culture of the institution - which, as presented, can be a barrier or a catalyst in the transition process. The whole system thinking envisaged by Sterling (2003) implies a cultural change.

\section{THE SUSTAINABLE UNIVERSITY - A MODEL FOR THE SUSTAINABLE ORGANIZATION}

Business is, directly or indirectly, the cause of most problems in the environment. It becomes increasingly evident that businesses are also those that should and can (both in terms of management and resources) address these issues. However, business community leaders ignore the studies about the ability to balance population growth, increasing consumption levels and threats to the natural environment. Education they have received in management school has indoctrinated them to prioritize increasing profits and shareholder value, not to recognize their actions as part of a finite, shared world. Recognition of the connection between environmental degradation and this dominant view of the purpose of schools reveals the deep need of a radically different vision of education. As David Orr [47] notes, "The crisis cannot be solved by the same kind of education that helped create the problems".

Benefits of implementing environmental and social initiatives must be quantified and expressed in business terms as relevant benefits in the medium and long term, to induce managers to make sustainable development a priority. Universities must educate future leaders of corporations and their employees to convince them that the adoption of responsible business strategies in terms of sustainability is a "win-win-win proposal for companies, environment and the society" [62].

Universities can shape the sustainable society both by educating the human resource and by inspiring the society and business community through the power of example. The presented model of a sustainable organization can be easily adapted by business organizations that want to green their infrastructure and production processes. Of course there are different issues that must be considered by production units, such as waste reduction, waste disposal, minimization of $\mathrm{CO} 2$ emissions and so on, but the main common feature that these organizations should share with the sustainable organization is the eco-mind-set. This mindset can be implemented through education, leading examples, constraints and pressure from the community, governments, customers and stakeholders and has proven to be a successful approach for many visionary entrepreneurs [63].

\section{CONCLUSIONS}

Sustainable development is the biggest challenge to universities in the twenty-first century [64]. Since there are many different definitions and interpretations of the concept, the strategies of the universities that are beginning to strive for sustainability show some differences. Various universities have already become engaged in the process of integrating sustainable development in their activities [64].

The sustainable university is not easy to be achieved, but all the efforts, energy, resources and time invested in many universities around the world show progress [11]. Implementing the proposed model for a sustainable university should be made through incremental steps, as shown, and should be a process of continual improvement in environmental, economic and social performance. The efforts of universities to become sustainable will inspire other organizations to embark in the process of becoming sustainable. 
Universities have different approaches of the transformation process towards a sustainable university. Some incorporated sustainability in their visions and missions; others focus on sustainability education or research integration, while others have created environmental policies or campus strategies, but what is desirable is an approach that incorporates all the components of the model. A holistic approach, based on the proposed model can transform the university into a sustainable one, encouraging students, professors and other members of the academic community to commit themselves to help society make the transition towards sustainable life styles.

Companies already know that their employees' sustainability literacy is important. Employees who have knowledge regarding sustainable development can help the business grow. In difficult economic times, sustainable development practices can save money and reduce environmental impact of the organization. Potential benefits for the implementation of Corporate Social Responsibility (CSR) and sustainability standards include lower prices for financial services, higher GDP growth and employment rate, equitable wealth distribution and long term sustainability in all areas of business [52]. Therefore, sustainability issues are relevant to organizations of all sizes and all sectors. Increasingly, organizations themselves are demanding sustainability literacy skills for a wide range of roles and responsibilities. If learners can gain these skills they are improving both their own employability as well as their ability to contribute to making their future workplace and society more sustainable [19].

The model presented in this paper can be a starting point for defining the model of a sustainable business organization and the guidelines for its implementation could be important tools for the managers of future green organizations.

Benefits of implementing environmental and social initiatives must be quantified and expressed in business terms as relevant benefits in the medium and long term, to induce managers to make sustainable development a priority. Universities must educate future leaders of corporations and their employees to convince them that the adoption of responsible business strategies in terms of sustainability is a "win-win-win proposal for companies, environment and the society" [62].

\section{ACKNOWLEDGEMENTS}

This work was supported by the strategic grant POSDRU/159/1.5/S/133255, Project ID 133255 (2014), cofinanced by the European Social Fund within the Sectorial Operational Program Human Resources Development 2007 2013

\section{REFERENCES}

1. Blewitt, J. (2006). The ecology of learning: Sustainability, lifelong learning, and everyday life. Sterling, VA: Earthscan.

2. Fien, J. (2002). Advancing Sustainability in Higher Education: Issues and Opportunities for Research. Higher Education Policy, 15, 143-152.

3. Filho, W. L. (Ed.). (2002b). International Experiences on Sustainability. Frankfurt am Main: Peter Lang.

4. Palmer, J. (1998). Environmental Education in the 21st Century: Theory, practice, progress and promise. London: Routledge.

5. Sterling, S. (2003). Whole systems thinking as a basis for paradigm change in education: explorations in the context of sustainability. PhD thesis. University of Bath. Available at: http://www.bath.ac.uk/cree/sterling.htm
6. Tilbury, D. (2004). Environmental Education for Sustainability: A force for change in higher education. In P. B Corcoran. \& A. E. J. Wals (Eds.), Higher Education and the Challenge of Sustainability: Problematics, promise and practice (pp. 97-112). Dordrecht: Kluwer Academic Press.

7. Posch, P. (1991): Environment and School Initiatives: Background and Basic Premises of the Project, in: OECD/CERI (Hrsg.) Environment and School Initiatives. Paris: OECD, $13-18$

8. Wals, A.E.J., Jickling, B. (2002) "Sustainability" in higher education: From doublethink and newspeak to critical thinking and meaningful learning", International Journal of Sustainability in Higher Education, Vol. 3 Iss: 3, pp.221 232

9. Association for Strengthening Agricultural Research in Eastern and Central Africa (ASARECA), (2008), Reshaping Tertiary Agricultural Education in the ACP: 2015 and Beyond, Electronic Newsletter, 27 June 2008, Volume 11, Number 12, accessed at: http://www.asareca.org/paap/uploads/newsletters/PAAP\% 20Newsletter\%20Vol\%2011\%20No\%2012.doc 21.09.2011

10. The Talloires Declaration, accessed 3.12.2010 from http://www.ulsf.org/programs_talloires.html

11. Velazquez, L, Munguia, N., Platt, A., Taddei, J. (2006) Sustainable university: what can be the matter?, Journal of Cleaner Production Volume 14, Issues 9-11, 2006, Pages 810-819 Sustainability In Higher Education: What is Happening?

12. Rappaport A, Creighton SH. (2007), Degrees that matter, climate change and the University. Cambridge, MA: MIT Press; 2007.

13. M'Gonigle M, Starke J, Planet U. (2006), Sustaining the World, reinventing the University. Gabriola Island. BC, Canada: New Society Publishers; 2006.

14. Cortese, A.D. (2008), Higher education's critical role in creating a healthy, just, and sustainable society. In: Simpson $\mathrm{W}$, editor. The Green Campus: meeting the challenge of environmental sustainability. Alexandria, Virginia: APPA; 2008.

15. Bowers CA. (2008) University reform in an era of global warming; 2008. Accessed at 20.11.2010 from: http://www.cabowers.net/pdf/Final-7chureform\%20(1).pdf

16. Davis, G., Wolski, M. (2009), E-waste and the sustainable organization: Griffith University's approach to e-waste. International Journal of Sustainability in Higher Education 2009; 10(1): 21. Accessed at 17.10.2010 from: http://www.emeraldinsight.com/journals.htm?articleid=17 69152\&show=html

17. Bursztyn M. (2008), Sustainability science and the University: towards interdicsiplinarity. In: Working Paper for Center for International Development at Harvard University, No. 24; 2008. Accesed 23.11.2010 from: http://www.hks.harvard.edu/centers/cid/publications/resear ch-fellow-graduate-student-working-papers/cid-graduatestudent-and-postdoctoral-fellow-working-paper-no.-24

18. Cortese, A.D. (1999) "Education for Sustainability: The University as a Model of Sustainability," available at: http://www.secondnature.org/pdf/snwritings/articles/univm odel.pdf retrieved o 22.09.2011

19. Robinson, Z., (2009) Greening Business - The ability to drive environmental and sustainability improvements in the workplace, Chapter 19, pp 130-136 in The Handbook of Sustainability Literacy, edited by Arran Stibbe 
20. Rennie, E. (2008a), Growing Green, Boosting the bottom line with sustainable business practices, APICS Magazine. Vol. 18, no. 2

21. United Nations General Assembly (1987), Report of the World Commission on Environment and Development: Our Common Future, Transmitted to the General Assembly as an Annex to document A/42/427 - Development and International Co-operation: Environment. Accessed in: 2009-02-15 at: http://www.un-documents.net/wcedocf.htm

22. Cooney, S. (2009), "Build A Green Small Business. Profitable ways to become an ecopreneur.", McGraw-Hill Publishing House, New York

23. Keijzers, G. (2002), The transition to the sustainable enterprise, Journal of Cleaner Production Volume 10, Issue 4, August 2002, Pages 349-359

24. Galvao, A. (2008), "The Next Ten Years: Energy and Environment.", Crossroads 2008 presentation, MIT TechTV beta, 55 min., 51 sec. available at http://techtv.mit.edu/videos/107

25. Matthews, R. (2009), What Constitutes a Green Business? Accessed at: http:/globalwarmingisreal.com/2009/09/16/whatconstitutes-a-green-business/ on 10.09.2011

26. Siegel, S., (2009), Green management matters only if it yields more green: an economic/strategic perspective. Academy of Management Perspectives volume 23, issue 3, pp5-16

27. Azapagic, A. and Perdan, S., (2000), Indicators of sustainable development for industry: a general framework, Trans IChemE, Part B, Proc Safe Env Prot, volume 78, issue 4, pp243-261

28. Azapagic, A. (2003), Systems Approach to Corporate Sustainability: A General Management Framework, Trans IChemE, Vol 81, pp303-316

29. Schaltegger, S. and Burritt, R., (2005), Corporate sustainability. In: Folmer, H., Tieten- berg, T. (Eds.), The International Yearbook of Environmental and Resource Economics. Edward Elgar, Cheltenham, pp. 185-232

30. van den Bosch, S.V.D. and Taanman, M (2006) 'How Innovation Impacts Society. Patterns and mechanisms through which innovation projects contribute to transitions'.Innovation Pressure Conference, 15th -17th March, Tampere, Finland

31. Mader, C. ,(2009), Principles for Integrative Development Process towards Sustainability in Regions - University of Graz, $140 \mathrm{p}$

32. Jayawardena, A., - What is the Sustainable University 21 (SU21) model?, available at: http://www.sustainableuni.kk5.org/\#/sustainableuniversity/4547096064 accessed on 10.09.2011

33. Velázquez Contreras, L.E., Munguía Vega, N.E., Esquer Peralta, J., Zavala Reyna,A. (2011), Sustainable Good Practices in the University of Sonora, Mexico, available at: http://www.guni-rmies.net/news/detail.php?id=1750, retrieved on 20.09.2011

34. Cotgrave, A.J., Kokkarinen, K., (2010) "Developing a model promoting sustainability literacy through construction curriculum design", Structural Survey, Vol. 28 Iss: 4, pp.266 - 280

35. University of Queensland, Australia, (2009)UQ Sustainability Framework Model, retrieved from: http://www.uq.edu.au/sustainability/uq-sustainabilityframework-model on 10.09.2011
36. Todorov, V.I. and D. Marinova (2009), Models of Sustainability, 18th World IMACS / MODSIM Congress, Cairns, Australia 13-17 July 2009, Available at: http://mssanz.org.au/modsim09, retrieved 12.10.2010

37. Lukman, R. and Glavic, P. (2007) What are the key elements of a sustainable university? Clean Technologies and Environmental Policy, 9(2), pp.103-114.

38. Jones, P., Selby, D. and Sterling, S. (2010b) More than the Sum of their Parts? Interdisciplinarity and Sustainability, Chapter 3, pp 39-54 in, Sustainability Education Perspectives and Practice Across Higher Education, edited by Paula Jones, David Selby and Stephen Sterling, Earthscan

39. Rhoen, D., Mansilla, V., Chun, M. and Klein, J.T. (2006) Interdisciplinary Education at Liberal Arts Institutions, Teagle Foundation White Paper, New York NY

40. Klein, J.T., (2006) A platform for shared discourse of interdisciplinary education, Journal of Social Science Education, vol 5, no 2, pp 10-18

41. Cotton, D. and Winter, J. (2010) It's not Just Bits of Paper and Light Bulbs: A Review of Sustainability Pedagogies and Their Potential for Use in Higher Education, Chapter 3, pp 39-54 in, Sustainability Education - Perspectives and Practice Across Higher Education, edited by Paula Jones, David Selby and Stephen Sterling, Earthscan

42. Naaranoja, M., Haapalainen, P. and Lonka, P., (2007), Strategic management tools in projects case construction project, International Journal of Project Management, Volume 25, Issue 7, October 2007, Pages 659-665

43. Hammond, S. (1998), Greening the Ivory Tower, MIT Press, Cambridge, MA

44. Barton, A. \& Dlouhá, J. (2011) Multi-Actor Learning for Sustainable Regional Development in Europe: A Handbook of Best Practice, Grosvenor House Publishing Ltd, Guildford, Surrey

45. Lee, S. (2006), Ten Ways to Increase Group Participation in Team Meetings, Retrieved 30.09.2011 from http://EzineArticles.com/2301823

46. Schumacher, E. F. (1997) This I Believe and Other Essays, Green Books, Dartington, UK

47. Orr, D. (2004) Earth in Mind: On Education, Environment, and the Human Prospect, Island Press, Washington DC

48. Sterling, S. (2004b). An Analysis of the Development of Sustainability Education Internationally: Evolution, Interpretation and Transformative Potential. In J. Blewitt \& C. Cullingford (Eds.), The Sustainability Curriculum: The Challenge for Higher Education (pp. 43-62). London: Earthscan Publications Ltd

49. Lindroos, P. (2007), From National to Global Cooperation - the Baltic Sea Region as an Example, in Kaivola, T. and Rohweder, L. (eds), Towards Sustainable Development in Higher Education - Reflections (2007), retrieved from http://www.minedu.fi/export/sites/default/OPM/Julkaisut/2 007/liitteet/opm06.pdf on 27.09.2011

50. Hart, P., Jickling, B. And Kool, R. (1998) Starting points: Questions of Quality in Environmental Education, in Jarnet et al., A Colloquium On - The Future of Environmental Education in a Postmodern World? Canadian Journal of Environmental Education, Whitehorse, Yukon

51. McKeown, R. (2002). The Education for Sustainable Development Toolkit. Retrieved 27.09.2011 from http://www.esdtoolkit.org.

52. Grecu, V., Deneş, C. (2011) Changing towards sustainability education - trends, barriers and possible 
solutions, Annals of the Constantin Brancusi University of Târgu Jiu, 2011,

53. Luukkonen, T., Nedeva, M. (2010) Towards understanding integration in research and research policy, Research Policy, Volume 39, Issue 5, June 2010, Pages 674-686, Retrieved 30.09.2011 from http://www.sciencedirect.com/science/article/pii/S0048733 310000569

54. Sherren, K., Klovdahl, A. S., Robin, L., Butler, L., \& Dovers, S. (2009) Collaborative research on sustainability: Myths and conundrums of interdisciplinary departments, Journal of Research Practice, 5(1), Article M1. Retrieved 07.10.2011,

from http://jrp.icaap.org/index.php/jrp/article/view/163/167

55. Turban, E., Sharda, R., Delen, D. King, D. and Aronson, J.E. (2010), Business Intelligence: A Managerial Approach, 2nd edition, Pearson Education Canada.

56. Morris, L, Stanton, P. and Young, S (2007) Performance Management in Higher Education: the Great Divide. In: Proceedings of the 21st Conference of the Association of Industrial Relations Academics of Australia and New Zealand, 7-9 February 2007, The University of Auckland, New Zealand

57. DeCieri, H. Kramar, R. (2005). Human resource management in Australia. 2nd Edition, McGraw-Hill, Macquarie Park, NSW
58. Ozga, J. (2003) Measuring and Managing Performance in Education, CES Briefing No. 27, Edinburgh: Centre for Educational Sociology, University of Edinburgh, Retrieved 10.10 .2011 from http://www.ces.ed.ac.uk/PDF\%20Files/Brief027.pdf

59. Oprean, C., Kifor, C.V., (2008) Quality Management , Callidus Publishing House, Germany

60. Selby, D. (2009) Towards the sustainability university: The Centre for Sustainable Futures, University of Plymouth, Journal of Education for Sustainable Development, vol 3, no 1, pp 103-106

61. Williams, P.M. (2008) University Leadership for Sustainability - A Dendritic Framework for Enablic Connection and Collaboration, $\mathrm{PhD}$ Thesis at Victoria University of Wellington, retrieved 20.07.2010 from http://www.futuresteps.co.nz/PhD_University_Leadership for_Sustainability.pdf

62. Willard, B. (2004), Teaching sustainability in business schools, Accessed la www.greenleafpublishing.com/content/pdfs/tbswilla.pdf in 20.05.2011

63. International Institute for Sustainable Development (IISD), (2010), accessed at http://www.iisd.org/business/ on 07.09.2011

64. van Weenen, H., (2000) "Towards a vision of a sustainable university", International Journal of Sustainability in Higher Education, Vol. 1 Iss: 1, pp.20 - 34 